\title{
Pectoralis Minor Syndrome Miscible with Subacromial Impingement Syndrome
}

\author{
Deniz Palamar, 'ilknur Aktaş, ${ }^{2}$ Kenan Akgün'
}

\author{
'Department of Physical Medicine \\ and Rehabilitation, İstanbul \\ University Cerrahpaşa Faculty of \\ Medicine, İstanbul, Turkey, \\ ${ }^{2}$ Department of Physical Medicine \\ and Rehabilitation, University \\ of Health Sciences Fatih Sultan \\ Mehmet Training and Research \\ Hospital, İstanbul, Turkey \\ Submitted: 03.10.2017 \\ Accepted: 09.10.2017 \\ Correspondence: Deniz Palamar, \\ İstanbul Üniversitesi Cerrahpaşa \\ Tıp Fakültesi, Fizik. Tıp ve \\ Reh. Anabilim Dalı, Istanbul, Turkey \\ E-mail: denizpalamar@gmail.com

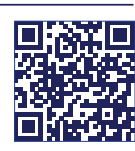 \\ Keywords: Muscle block; \\ pectoralis minor syndrome; \\ subacromial impingement \\ syndrome; ultrasonography.
}

\begin{abstract}
Objective: Pectoralis minor syndrome (PMS) is a neurovascular disorder affecting the upper extremity. In the present study, the demographic and clinical features of patients diagnosed as PMS were examined, as well as cases of concomitant subacromial impingement syndrome (SIS).
\end{abstract}

Methods: A retrospective trial was conducted with 12 patients with the diagnosis of PMS according to a pectoralis minor muscle (PMM) block test. The PMM block was performed under the guidance of ultrasonography.

Results: Of the 12 PMS patients evaluated, $83 \%$ had a complaint of pain, $58.3 \%$ had paresthesia, and $16.6 \%$ had swelling of the hand. A physical examination revealed that $58.3 \%$ of the patients had tenderness at the biceps tendon, $16.6 \%$ had subacromial tenderness, and $16.6 \%$ had tenderness at the acromioclavicular joint. In $66.6 \%$ patients, subacromial impingement tests were positive, and $33.3 \%$ of them had a positive subacromial injection test (SIT).

Conclusion: PMS can be overlooked and may also be confused with other disorders, such as SIS. Furthermore, SIS may also accompany PMS. Therefore, in such painful pathologies, injection tests such as SIT and PMM block should be used as the reference test for the diagnosis and it should be kept in mind that these 2 clinical disorders can be observed together.

\section{INTRODUCTION}

Thoracic outlet syndrome (TOS) is a neurovascular disorder affecting the upper extremity. This disorder presents with pain, paresthesia, and weakness in the upper extremity, and may also include coldness and color changes in the hands, especially with overhead activities. It is often misdiagnosed, since the diagnosis cannot be made by X-ray or nerve tests and requires clinical evaluation with history and a physical examination. According to the classic concept, there are 3 major sites for neurovascular compression of the subclavian artery, subclavian vein, and brachial plexus: the interscalene triangle, costoclavicular triangle, and retropectoralis minor space. But according to another concept, compression of the neurovascular bundle can occur above or below the clavicle. Above the clavicle, compression occurs in the scalene triangle producing TOS; below the clavicle, it occurs at the retropectoralis minor space, producing pectoralis minor syndrome (PMS).$^{[1]}$ Diagnostic injection testing is required to differentiate between the associated conditions and appropriate medical or surgical treatments for each compression syndrome are recommended. ${ }^{[1]}$ Tenderness at the biceps and rotator cuff tendons, and also at the trapezius and rhomboid muscles may be found. ${ }^{[2]}$ This may lead to a false diagnosis of subacromial impingement syndrome (SIS). For the diagnosis of PMS, a diagnostic pectoralis minor muscle (PMM) block is performed. Ultrasonography can be used for diagnostic muscle injections and also for treatment of TOS. ${ }^{[3]}$

The present study was a retrospective look at the demographic and clinical features of patients diagnosed as PMS and cases of concomitant SIS.

\section{MATERIAL AND METHODS}

A retrospective trial was conducted. Twelve $(n=12)$ patients between the ages of 12 and 70 years with a diagnosis of PMS according to a PMM block test were included in the study. The exclusion criteria were a history of a neurological disorder or operation in the shoulder region that might affect upper extremity functions, being in a gestational or lactational period, history of allergic reaction to 
the substance to be applied as a local anesthetic, history of anticoagulation use, presence of a psychiatric disorder and cognitive dysfunction, uncontrolled hypertension, uncontrolled diabetes mellitus, noncompensated chronic heart/ liver/renal deficiency, and vascular/tumoral disease.

Data on demographic details, handedness, duration of complaints, aggravating factors, possible causative factors, history of trauma, and medical history were evaluated in the outpatient clinic by a single physiatrist. Physical examination of the shoulder and cervical spine was assessed to exclude other causes of pain. Subacromial impingement tests and provocative maneuvers for TOS were performed. In a neurological examination, muscle strength, cutaneous sensation, deep tendon and pathological reflexes were assessed. An ultrasound-guided subacromial injection test (SIT) was performed on patients with a positive impingement test. The SIT was accepted as positive in patients with significant pain reduction of minimum $50 \%$.

\section{Ultrasound-guided pectoralis minor muscle block procedure}

For the diagnosis of PMS, a PMM block was performed. A good response to the block was accepted as loss of tenderness over the PMM, and significant relief of most symptoms I hour after application of the block. PMS was diagnosed in patients whose complaints resolved at least $50 \%$ from the baseline after the injection. The PMM block was performed under the guidance of ultrasonography by the same physiatrist (IA), who was experienced with interventional procedures. All procedures were performed with a 7-I3 MHz linear probe (LOGIQ P5; GE Healthcare Inc. Chicago, IL, USA).

During the procedure, all of the patients assumed a supine position. The coracoid process was identified first, and the transducer was advanced medially. After locating the PMM under the pectoralis major muscle and above the neurovascular structures, the injection was performed with a 22-G needle using the in-plane technique to the point of maximum tenderness (Fig. I).

\section{Statistical analysis}

All statistical analyses were performed using SPSS for Windows, Version 10.0 (SPSS, Inc., Chicago, IL, USA) software. Descriptive statistics of continuous variables were expressed as mean $\pm \mathrm{SD}$ and categorical variables as percentages.

\section{RESULTS}

In total, I 2 patients (I man, II women) whose PMM block was positive and diagnosed as PMS and who fulfilled the inclusion criteria were evaluated. Of the group, $8.4 \%$ were men and $91.6 \%$ were women. The mean age of the patients was $46.88 \pm 21.44$ years. The mean body mass index was $24.47 \pm 2.8 \mathrm{I} \mathrm{kg} / \mathrm{m}^{2}$. The demographic data of the study patients are provided in Table I.

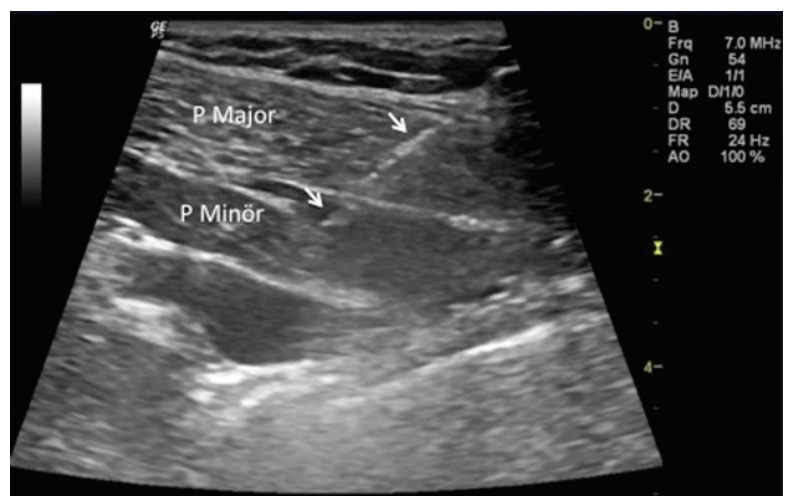

Figure 1. Ultrasound-guided pectoralis minor muscle block. $\mathrm{P}$ Major: Pectoralis major muscle; P Minor: Pectoralis minor muscle; White arrow: Needle.

The mean complaint duration was 24.36 months (range: I-72 months). Seven patients (58.33\%) had complaints in the dominant extremity, 4 patients $(33.33 \%)$ in the nondominant extremity, and I patient had complaints on both sides. When the patients were evaluated in terms of their symptoms, $83 \%$ had a complaint of pain, $58.3 \%$ had paresthesia, and $16.6 \%$ had swelling of the hand. None of the patients had coldness or pale coloration of the hand. Physical examination revealed that $58.3 \%$ of the patients had tenderness at the biceps tendon, $16.6 \%$ had subacromial tenderness, and $16.6 \%$ had tenderness at the acromioclavicular joint. In $66.6 \%$ of the patients, the subacromial impingement test was positive, and a SIT was performed. The SIT was accepted as positive in $33.3 \%$ of patients with significant pain reduction of a minimum of $50 \%$. For those with ongoing paresthetic complaints and tenderness over the PMM, a PMM block was performed and they were diagnosed as PMS. Electromyogram study results were normal for all of the patients. In I patient, axillary artery compression under the PMM was detected with Doppler ultrasonography.

\section{DISCUSSION}

The diagnosis of PMS can be overlooked, and the condition can be confused with other disorders, such as rotator cuff tendon pathologies. Furthermore, rotator cuff tendon pathologies may also accompany PMS. To our knowledge, in the English-language literature, there are no data about the coexistence of these 2 pathologies.

Table I. Demographic data of the patients

\begin{tabular}{ll}
\hline & Mean \pm SD \\
\hline Age (years) & $46.88 \pm 21.44$ \\
Height $(\mathrm{cm})$ & $162.30 \pm 8.78$ \\
Weight $(\mathrm{kg})$ & $62.54 \pm 9.13$ \\
Body mass index $\left(\mathrm{kg} / \mathrm{m}^{2}\right)$ & $24.47 \pm 2.81$ \\
\hline
\end{tabular}

SD: Standard deviation. 
In the present study, we retrospectively looked into the demographic and clinical features of patients diagnosed as PMS, and also looked for concomitant SIS. The majority of our cases $(58.33 \%)$ had symptoms on the dominant side, but I patient had complaints on both sides. Pain, paresthesia, and weakness are the common symptoms of neurogenic TOS and PMS. Paresthesia commonly involves all of the fingers, with more involvement of the fourth and fifth fingers. Pain may be felt at the neck region, the trapezius, supraclavicular area, over the pectoralis minor tendon, the shoulder, and toward the hand. ${ }^{\left[{ }^{[]}\right.}$In the physical examination, in addition to PMM tenderness, pain over the biceps, rotator cuff tendons, trapezius, and rhomboid muscles may be observed. ${ }^{[2]}$ With all of these physical examination findings and complaints, the patient may be diagnosed as SIS. For this reason, diagnostic injection tests are very helpful in a differential diagnosis. For the diagnosis of SIS, SIT should be performed. ${ }^{[4,5]}$

When clinically suspicious of PMS, muscle blocks with a local anesthetic must be done to confirm a PMS diagnosis. ${ }^{[1,2]}$ Injection of lidocaine into the PMM and the anterior scalene muscle is a very useful test to confirm a diagnosis of neurogenic TOS and neurogenic PMS. The block is performed by injecting $4 \mathrm{~mL}$ of $2 \%$ lidocaine into the PMM under the guidance of ultrasonography. A successful block is indicated by loss of tenderness in the area and significant relief of most symptoms. A PMM block can be performed with landmark techniques. ${ }^{[2]}$ But due to the proximity of neurovascular structures and for accurate needle localization, imaging-guided methods are recommended. An ultrasound-guided PMM block technique has previously been described..$^{[3,6]}$ This technique has a greater success rate and might allow a more precise block of the PMM. In addition, with ultrasonographic assessments, anatomical variations, PMM thickness, and relationships to surrounding structures can be visualized.

The most common complaint in our patients was pain (83\%), followed by paresthesia (58.3\%). More than half of our patients had bicipital tendon sensitivity, and in $66.6 \%$ of the patients, the subacromial impingement test was positive. All of these examinations and complaints could lead to a misdiagnosis. In approximately $30 \%$ of our patients, the SIT was positive and these patients were diagnosed as SIS as well as PMS. Therefore, we can conclude that in such painful pathologies, injection tests, such as SIT and PMM block should be used as the reference test for the diagnosis. Also, it should be kept in mind that these 2 clinical disorders can occur together.

Ethics Committee Approval

The approval of the local Ethics Committee was obtained. Informed Consent

Approval was obtained from the patients.

Peer-review

Internally peer-reviewed.

Authorship Contributions

Concept: K.A.; Design: K.A., I.A., D.P.; Data collection \&/ or processing: I.A.; Analysis and/or interpretation: D.P.; Literature search: D.P.; Writing: D.P., I.A., K.A.; Critical review: K.A., I.A., D.P.

Conflict of Interest

None declared.

\section{REFERENCES}

1. Sanders RJ, Annest SJ. Thoracic outlet and pectoralis minor syndromes. Semin Vasc Surg 2014;27:86-117. [CrossRef]

2. Sanders RJ, Annest SJ. Pectoralis Minor Syndrome: Subclavicular Brachial Plexus Compression. Diagnostics (Basel) 2017;7. pii: E46.

3. Torriani M, Gupta R, Donahue DM. Botulinum toxin injection in neurogenic thoracic outlet syndrome: results and experience using a ultrasound-guided approach. Skeletal Radiol 2010;39:973-80.

4. Neer CS 2nd. Impingement lesions. Clin Orthop Relat Res 1983;70-7.

5. Caliş M, Akgün K, Birtane M, Karacan I, Caliş H, Tüzün F. Diagnostic values of clinical diagnostic tests in subacromial impingement syndrome. Ann Rheum Dis 2000;59:44-7. [CrossRef]

6. Bottros MM, AuBuchon JD, McLaughlin LN, Altchek DW, Illig KA, Thompson RW. Exercise-Enhanced, Ultrasound-Guided Anterior Scalene Muscle/Pectoralis Minor Muscle Blocks Can Facilitate the Diagnosis of Neurogenic Thoracic Outlet Syndrome in the HighPerformance Overhead Athlete. Am J Sports Med 2017;45:189-94.

\section{Subakromiyal Sıkışma Sendromu ile Karıştırılabilen Pektoralis Minör Sendromu}

Amaç: Pektoralis minör sendromu (PMS), üst ekstremiteyi etkileyebilen nörovasküler bir hastalıktır. Bu çalışmada, PMS tanısı alan hastalar demografik ve klinik özellikleri ve eşlik eden subakromiyal sıkışma sendromu açısından değerlendirildi.

Gereç ve Yöntem: Pektoralis minör kas bloğu ile PMS tanısı konulan 12 ve 70 yaş arasındaki 12 hasta geriye dönük olarak değerlendirildi. Pektoralis minör kas bloğu ultrasonografi rehberliğinde uygulandı.

Bulgular: Toplam 12 hasta değerlendirildi. Hastaların \%83'ünde ağrı, \%58.3'ünde parestezi ve \%।6.6'sında şişlik yakınması mevcuttu. Fizik muayenede, hastaların \%58.3'ünde biseps tendonunda hassasiyeti, \%16.6'sında subakromiyal hassasiyet ve \% 16.6 'sında akromioklaviküler eklem hassasiyeti saptandı. Hastaların \%66.6'sında subakromiyal sıkışma testleri pozitif saptandı, \%33.3'ünde ise subakromiyal enjeksiyon testi pozitif olarak değerlendirildi.

Sonuç: Pektoralis minör sendromu, gözden kaçabilen bir tanıdır ve subakromiyal sıkışma sendromu gibi başka diğer hastalıklarla karışabilir. Bunun yanında, subakromiyal sıkışma sendromu PMS'ye eşlik edebilir. Bu nedenle, bu tür ağrılı patolojilerde tanı için, referans test olarak subakromiyal enjeksiyon testi ve pektoralis minör kas bloğu gibi enjeksiyon testleri kullanılmalı ve bununla birlikte bu iki klinik tablonun birlikte görülebileceği de akılda tutulmalıdır.

Anahtar Sözcükler: Kas bloğu; pektoralis minör sendromu; subakromiyal sıkışma sendromu; ultrasonografi. 